\title{
Pro-inflammatory adjuvant properties of pigment-grade titanium dioxide particles are augmented by a genotype that potentiates interleukin $1 \beta$ processing
}

Sebastian Riedle ${ }^{1,2,3}$, Laetitia C. Pele ${ }^{4}$, Don E. Otter ${ }^{1,5}$, Rachel E. Hewitt ${ }^{4,6}$, Harjinder Singh ${ }^{2}$, Nicole C. Roy ${ }^{1,2+}$ and Jonathan J. Powell ${ }^{4,6^{*}+}$

\begin{abstract}
Background: Pigment-grade titanium dioxide $\left(\mathrm{TiO}_{2}\right)$ particles are an additive to some foods (E171 on ingredients lists), toothpastes, and pharma-/nutraceuticals and are absorbed, to some extent, in the human intestinal tract. $\mathrm{TiO}_{2}$ can act as a modest adjuvant in the secretion of the pro-inflammatory cytokine interleukin $1 \beta(\mathrm{IL}-1 \beta)$ when triggered by common intestinal bacterial fragments, such as lipopolysaccharide (LPS) and/or peptidoglycan.

Given the variance in human genotypes, which includes variance in genes related to IL-1 $\beta$ secretion, we investigated whether $\mathrm{TiO}_{2}$ particles might, in fact, be more potent pro-inflammatory adjuvants in cells that are genetically susceptible to IL-1 $\beta$-related inflammation.

Methods: We studied bone marrow-derived macrophages from mice with a mutation in the nucleotide-binding oligomerisation domain-containing 2 gene $\left(\mathrm{Nod}_{2}^{\mathrm{m} / \mathrm{m}}\right)$, which exhibit heightened secretion of IL-1 $\beta$ in response to the peptidoglycan fragment muramyl dipeptide (MDP). To ensure relevance to human exposure, $\mathrm{TiO}_{2}$ was food-grade anatase (119 $\pm 45 \mathrm{~nm}$ mean diameter \pm standard deviation). We used a short 'pulse and chase' format: pulsing with LPS and chasing with $\mathrm{TiO}_{2}+/-$ MDP or peptidoglycan.

Results: IL-1 $\beta$ secretion was not stimulated in LPS-pulsed bone marrow-derived macrophages, or by chasing with MDP, and only very modestly so by chasing with peptidoglycan. In all cases, however, IL-1 $\beta$ secretion was augmented by chasing with $\mathrm{TiO}_{2}$ in a dose-dependent fashion (5-100 $\mu \mathrm{g} / \mathrm{mL}$ ). When co-administered with MDP or peptidoglycan, $\mathrm{IL}-1 \beta$ secretion was further enhanced for the Nod2 ${ }^{\mathrm{m} / \mathrm{m}}$ genotype. Tumour necrosis factor a was triggered by LPS priming, and more so for the Nod2 $2^{\mathrm{m} / \mathrm{m}}$ genotype. This was enhanced by chasing with $\mathrm{TiO}_{2}, \mathrm{MDP}$, or peptidoglycan, but there was no additive effect between the bacterial fragments and $\mathrm{TiO}_{2}$.

Conclusion: Here, the doses of $\mathrm{TiO}_{2}$ that augmented bacterial fragment-induced IL-1 $1 \beta$ secretion were relatively high. In vivo, however, selected intestinal cells appear to be loaded with $\mathrm{TiO}_{2}$, so such high concentrations may be 'exposure-relevant' for localised regions of the intestine where both $\mathrm{TiO}_{2}$ and bacterial fragment uptake occurs. Moreover, this effect is enhanced in cells from Nod2 $2^{\mathrm{m} / \mathrm{m}}$ mice indicating that genotype can dictate inflammatory signalling in response to (nano)particle exposure. In vivo studies are now merited.
\end{abstract}

Keywords: Nano, Particle, $\mathrm{TiO}_{2}$, E171, NOD2, IL-1ß, TNF-a, Muramyl dipeptide, Peptidoglycan

\footnotetext{
* Correspondence: jonathan.powell@mrc-ewl.cam.ac.uk

${ }^{\dagger}$ Equal contributors

${ }^{4}$ Biomineral Research Group, MRC Human Nutrition Research, Elsie

Widdowson Laboratory, 120 Fulbourn Road, Cambridge CB1 9NL, UK

${ }^{6}$ Department of Veterinary Medicine, Biomineral Research Group, University

of Cambridge, Madingley Road, Cambridge CB3 OES, UK

Full list of author information is available at the end of the article
} 


\section{Background}

Potential toxicological effects following exposure to titanium dioxide $\left(\mathrm{TiO}_{2}\right)$ are of current interest [1, 2]. $\mathrm{TiO}_{2}$ is a mineral pigment which, when used in a particulate form, is valued for its properties as a whitening or brightening agent, and is included in some processed foods (E171 on ingredients lists), toothpastes, capsules and tablets. From these sources, the average daily intake of pigment-grade $\mathrm{TiO}_{2}$ for an adult in the UK is about $10^{12}$ particles/day [3, 4], nominally $\sim 0.04 \mathrm{mg} / \mathrm{kg} /$ day for a $70 \mathrm{~kg}$ adult. These findings are supported by a recent Dutch study with mean long term intakes of pigmentgrade $\mathrm{TiO}_{2}$ ranging from $0.06 \mathrm{mg} / \mathrm{kg} /$ day in elderly subjects to $0.17 \mathrm{mg} / \mathrm{kg} /$ day for 7-69-year-olds [5]. In 2-6 year old children, however, it was higher at $0.67 \mathrm{mg} / \mathrm{kg} /$ day [5].

It is well established that particles of $\mathrm{TiO}_{2}$, likely derived from sources of the Western lifestyle described above, accumulate in certain cells, such as macrophages in Peyer's patches of the human small intestine [6-10]. Whether they have any deleterious impact in this environment remains a matter of speculation, but, if they do, both cell accumulation and host factors are likely to be important [4]. Indeed, it has been often noted that the accumulation of these particles occurs where the earliest signs of Crohn's disease have been reported [11]. With respect to cell accumulation and stimulation, the pristine particle is probably of limited relevance. The intestinal lumen is a 'soup' of proteins, bacterial fragments, ions, small organic molecules etc. and these will modify the surface of the particles through adsorptive interactions. Consistent with this, there are several reports of how $\mathrm{TiO}_{2}$ particles act as an adjuvant for cellular responses to the bacterial-derived molecule lipopolysaccharide (LPS), either through formation of 'conjugates' or by coincubation [12-15].

More recently it has been shown that pigment-grade $\mathrm{TiO}_{2}$ is a modest trigger of the NLR family pyrin domain-containing 3 (NLRP3) inflammasome and that this activity may contribute to intestinal inflammatory properties of the particle in murine models [16]. The inflammasome regulates the activation of caspase-1 which, in turn, determines cleavage of inactive pro-interleukin $1 \beta$ (pro-IL-1 $1 \beta$ ) to form mature pro-inflammatory interleukin $1 \beta$ (IL-1 $\beta)$. If such a pro-inflammatory effect from oral $\mathrm{TiO}_{2}$ exposure translates significantly from murine models to humans, it must be occurring in a small minority of the population because most children and adults do not have intestinal disease. In this respect some variants of human genotype could be important. Indeed, it is well recognised that inflammatory bowel diseases are complex polygenic disorders [17]. Certain mutations in the nucleotide-binding oligomerisation domain-containing 2 (NOD2) gene, for example, are associated with an increased risk of the inflammatory bowel disease, Crohn's disease [18, 19]. Maeda et al. have shown that in mice at least one form of Nod2 mutation potentiates IL-1 $\beta$ processing and enhances risk of intestinal inflammation [20]. These mice carry a known Crohn's disease-associated 'knockin' mutation in the Nod2 locus but also carry a duplication of the 3' end of the wild-type (WT) Nod2 locus [21], and herein are designated as $N o d 2^{\mathrm{m} / \mathrm{m}}$ mice. Specifically, development of a modest pro-inflammatory phenotype in these animals is reportedly triggered by a bacterial peptidoglycan moiety, muramyl dipeptide (MDP), in an IL-1 $\beta$-dependent fashion [20]. Since bacterial peptidoglycan is taken up by Peyer's patch phagocytes $[22,23]$ it raises the possibility that $\mathrm{TiO}_{2}$ could act as an adjuvant for the proinflammatory effects of peptidoglycan, and especially so where the genotype potentiates IL- $1 \beta$ processing. Hence, using bone marrow-derived macrophages (BMDMs) from WT and $N o d 2^{\mathrm{m} / \mathrm{m}}$ mice, we have tested these possibilities using an assay of short 'pulse and chase' format, to determine if and how $\mathrm{TiO}_{2}$ could amplify IL- $1 \beta$ secretion at the cellular level.

\section{Methods}

Study design

The macrophage-stimulatory effects of dietary $\mathrm{TiO}_{2}$ were investigated, either alone or in combination with microbial-associated molecular patterns (MAMPs), using cells from WT and Nod $2^{\mathrm{m} / \mathrm{m}}$ mice. MAMP concentrations were fixed whereas a range of $\mathrm{TiO}_{2}$ concentrations was investigated. LPS pre-stimulation of cells was employed as this MAMP is abundant in the intestinal lumen and can prime cells for an inflammasome-driven response (IL-1 $\beta$ secretion), as described in the Introduction. Parameters assessed were overall cell viability, particle uptake, and secretion of the pro-inflammatory cytokines IL-1 $\beta$ and tumour necrosis factor alpha (TNF- $\alpha)$.

\section{$\mathrm{TiO}_{2}$ particles}

Food- and pharmaceutical-grade $\mathrm{TiO}_{2}$ particles with anatase crystal structure and a purity of not less than $99 \%$ were obtained from Sensient Colors (St. Louis, USA). According to the manufacturer, the $\mathrm{TiO}_{2}$ particles had an average particle size of $300 \mathrm{~nm}$ and a maximum particle size of $1.0 \mu \mathrm{m}$, which had been determined using a sediograph instrument. We undertook further analysis of the powder, initially with transmission electron microscopy. A $1 \mathrm{mg} / \mathrm{mL}$ suspension of $\mathrm{TiO}_{2}$ powder in distilled water (Life Technologies, Auckland, New Zealand) with $0.5 \%$ bovine serum albumin (BSA; Life Technologies) as a dispersant was prepared. A drop of the $\mathrm{TiO}_{2}$ particle suspension was placed on a 200-mesh carbon-coated copper grid, and excessive liquid was absorbed with filter paper. The particles were analysed with a Philips CM10 transmission electron microscope at $80 \mathrm{kV}$. The image 
analysis software iTEM (Olympus Soft Imaging Solutions, Münster, Germany) was used to record the images digitally and subsequently measure the diameter of the particles.

In addition, particle size under cell culture conditions was determined with nanoparticle tracking analysis, which is a method to analyse dispersed particles based on their Brownian motion, similar to analysis with dynamic light scattering [24]. A $100 \mu \mathrm{g} / \mathrm{mL} \mathrm{TiO}_{2}$ particle suspension was prepared in tissue culture medium (TCM) consisting of RPMI 1640 medium (Sigma-Aldrich, Gillingham, UK) with $10 \%$ foetal bovine serum (FBS; PAA Laboratories, Yeovil, UK) and $1 \%$ penicillinstreptomycin antibiotics (Sigma-Aldrich). The suspension was sonicated for $10 \mathrm{~min}$ to facilitate distribution of the $\mathrm{TiO}_{2}$ particles in the medium. The motion of the particles in suspension was digitally recorded with a NanoSight NS500 instrument (NanoSight, Amesbury, UK). Three $\mathrm{TiO}_{2}$ suspensions were analysed independently. The particle sizes were calculated from the recorded videos with nanoparticle tracking analysis software (Nanosight).

\section{Animals}

For the cell culture experiments, bone marrow was obtained from 10 to 18 week old female C57BL/6 WT and $\operatorname{Nod} 2^{\mathrm{m} / \mathrm{m}}$ mice. The original WT breeding pairs were purchased from the Jackson Laboratory (Bar Harbor, USA) and bred at the AgResearch Small Animal Colony (Hamilton, New Zealand). Breeding pairs for $N o d 2^{\mathrm{m} / \mathrm{m}}$ mice on a C57BL/6 background were kindly provided by Lars Eckmann [20], and backcrossed with WT mice for 10 generations at the AgResearch Small Animal Colony. The mice were kept under conventional conditions at all times [25].

\section{Harvest of BMDMs and cell culture}

For the bone marrow collection, the mice were euthanised with $\mathrm{CO}_{2}$ asphyxiation and cervical dislocation. Femurs and tibias were collected, sterilised in $70 \%$ ethanol for $10 \mathrm{~s}$, and the bone marrow flushed out with cold RPMI 1640 medium (Life Technologies). Single cell suspensions were prepared by passing the cells repeatedly through a 19G needle (BD Biosciences, Singapore) and a $70 \mu \mathrm{m}$ cell strainer (BD Labware, Franklin Lakes, USA). Bone marrow cells were re-suspended in TCM consisting of RPMI 1640 medium (Life Technologies) with 10\% FBS (Life Technologies), 1\% penicillin-streptomycin antibiotics (Life Technologies), and $10 \mu \mathrm{g} / \mathrm{mL}$ macrophage colony-stimulating factor (eBioscience, San Diego, USA). The cells were transferred to non-tissue culture treated 24-well plates (BD Labware) at a concentration of $1 \times$ $10^{6}$ cells/well in $1 \mathrm{~mL}$ TCM and cultured at $37{ }^{\circ} \mathrm{C}$ in $7 \%$ $\mathrm{CO}_{2} / 93 \%$ air. Half of the TCM was replaced every 3 days with fresh TCM throughout the culture period. Bone marrow cells were fully differentiated into BMDMs on day 7 and used for experiments between day 8 and day 10 .

\section{Stimulation of BMDMs with $\mathrm{TiO}_{2}$ particles +/- peptidoglycan or MDP}

As previously noted, a short 'pulse (LPS) and chase $\left(\mathrm{TiO}_{2}+/\right.$ - peptidoglycan or MDP)' format was used to dissect out the point in the pathway that the particles might act as pro-inflammatory adjuvants of MAMPs. To that effect, harvested murine BMDMs from each genotype, +/- LPS pre-stimulation, were exposed to a range of $\mathrm{TiO}_{2}$ particle concentrations +/- peptidoglycan or MDP, as detailed below.

To activate the cells, especially for pro-IL- $1 \beta$ induction, BMDMs were first primed in culture with $1 \mathrm{~mL}$ TCM containing $10 \mathrm{ng} / \mathrm{mL}$ LPS from Escherichia coli O111:B4 (Sigma-Aldrich, Auckland, New Zealand) for $3 \mathrm{~h}$ at $37{ }^{\circ} \mathrm{C}$ in $7 \% \mathrm{CO}_{2} / 93 \%$ air. Unprimed BMDMs were cultured under identical conditions but without LPS. All cells were then washed in TCM before the $\mathrm{TiO}_{2}$ suspensions were added. A $1 \mathrm{mg} / \mathrm{mL} \mathrm{TiO}_{2}$ stock suspension was first prepared in distilled water and autoclaved. This stock suspension was used to prepare $\mathrm{TiO}_{2}$ suspensions in the TCM with final concentrations from $5 \mu \mathrm{g} / \mathrm{mL}$ to $100 \mu \mathrm{g} / \mathrm{mL}$. Similar concentrations have been used in previous studies that examined cytokine secretion by phagocytic cells after $\mathrm{TiO}_{2}$ exposure [13, 26-28]. The $\mathrm{TiO}_{2}$ suspensions were sonicated in a water bath for $10 \mathrm{~min}$ before $1 \mathrm{~mL}$ of the respective $\mathrm{TiO}_{2}$ suspension was added to the cells. When the BMDMs were co-stimulated with MAMPs, either synthetic MDP or peptidoglycan from Bacillus subtilis (both from Sigma-Aldrich) was added to the respective $\mathrm{TiO}_{2}$ suspensions in TCM, both at a final concentration of $10 \mu \mathrm{g} / \mathrm{mL}$. The BMDMs were incubated with $\mathrm{TiO}_{2}$ particles in TCM with or without the co-stimulants for $3 \mathrm{~h}$ at $37{ }^{\circ} \mathrm{C}$ in $7 \% \mathrm{CO}_{2} / 93 \%$ air.

\section{Flow cytometry analysis of BMDMs}

Only LPS pre-stimulated BMDMs were used for flow cytometry analysis. After incubation with particle suspensions with or without the other MAMPs, the cells were collected for analysis with flow cytometry. Briefly, cells were washed with TCM, incubated for $30 \mathrm{~min}$ with cold phosphate-buffered saline (PBS; Life Technologies) on ice, and collected by vigorous pipetting. The BMDMs were re-suspended in $150 \mu \mathrm{L}$ PBS containing 5\% FBS, $2 \%$ ethylenediaminetetraacetic acid (Life Technologies), and $1 \%$ sodium azide (BDH Laboratory Supplies, Poole, UK). The cells were first incubated for $15 \mathrm{~min}$ on ice with $1 \mu \mathrm{g} / \mathrm{mL}$ anti-mouse CD16/32 blocking antibody (clone 93; BioLegend, San Diego, USA) and then stained for $15 \mathrm{~min}$ on ice with $1 \mu \mathrm{g} / \mathrm{mL}$ anti-mouse 
phycoerythrin-labelled F4/80 antibody (clone BM8; BioLegend), a specific marker for murine macrophages. In addition, $0.8 \mu \mathrm{g} / \mathrm{mL}$ propidium iodide (PI; Life Technologies) was added to each sample immediately before analysis for viability assessment. The cells were analysed with a FACS Calibur flow cytometer (BD Biosciences, San Jose, USA), and at least 12,000 events per sample were acquired with the CellQuest Pro software (BD Biosciences). Data analysis was performed with FlowJo (Tree Star, Ashland, USA). For details on the gating strategy see Additional file 1. The percentage of viable cells in relation to the total number of detected events was assessed with PI staining. Cells that did not show PI staining $\left(\mathrm{PI}^{-}\right)$were considered to be viable cells. BMDMs were identified among the $\mathrm{PI}^{-}$cells based on the expression of $F 4 / 80$, i.e. viable cells that expressed $\mathrm{F} 4 / 80\left(\mathrm{PI}^{-} \mathrm{F} 4 / 80^{+}\right)$were classified as viable BMDMs. The percentages of $\mathrm{PI}^{-} \mathrm{F} 4 / 80^{+}$cells in relation to the total number of viable cells are shown in Additional file 2 . Uptake of $\mathrm{TiO}_{2}$ particles by BMDMs was assessed with the median side scatter (SSC) intensity of the $\mathrm{PI}^{-} \mathrm{F} 4 / 80^{+}$cell populations. According to previous studies, an increase in SSC intensity indicated $\mathrm{TiO}_{2}$ particle uptake [12, 29, 30].

\section{Validation of SSC analysis by flow cytometry as a measure of $\mathrm{TiO}_{2}$ cellular uptake}

To confirm that increases in SSC intensity did indeed indicate $\mathrm{TiO}_{2}$ particle uptake, we undertook correlative studies with conventional flow cytometry and imaging cytometry which allows visualisation of $\mathrm{TiO}_{2}$ uptake by individual cells [31]. This technique was not available in the laboratory that undertook the above work and is impractical for a very large number of samples, so only the lower concentration range was investigated and correlated to ensure true discrimination from background.

To quantify $\mathrm{TiO}_{2}$ cellular uptake (i.e. association and localisation) by peripheral myeloid cell populations, fresh leukocyte cones were purchased from the National Blood Service (Cambridge, UK). Peripheral blood mononuclear cells (PBMCs) were isolated by density centrifugation using the separating medium Lymphoprep (Axis Shield Diagnostics, Dundee, UK) and frozen until use. PBMCs from 3 leucocyte cones were thawed and rested for $2 \mathrm{~h}$ prior to incubation at $1 \times 10^{6}$ cells $/ \mathrm{mL}$ with $0 \mu \mathrm{g} / \mathrm{mL}, 5 \mu \mathrm{g} / \mathrm{mL}$, or $10 \mu \mathrm{g} / \mathrm{mL} \mathrm{TiO}_{2}$ and incubated for $24 \mathrm{~h}$ in RPMI 1640 medium (SigmaAldrich, Gillingham, UK) supplemented with $10 \%$ FBS (Sigma-Aldrich).

After incubation, cells were washed with ice cold PBS (Sigma-Aldrich) containing 1\% BSA (Sigma-Aldrich) and stained for the human monocyte/myeloid cell markers CD14 Alexa Fluor 488 or CD11c fluorescein isothiocyante (both from BD Biosciences), respectively. Single stain compensation tubes and unstained PBMC tubes, with and without $\mathrm{TiO}_{2}$, were also prepared at this time from PBMC samples for the generation of compensation matrices. After staining, PBMCs were washed with ice cold PBS containing 1\% BSA, re-suspended in a small volume of PBS containing 2\% paraformaldehyde (SigmaAldrich) solution, and placed on ice in the dark until acquisition.

Imaging cytometry analysis was undertaken using an ImageStreamX Mark I platform (Amnis-Merck-Millipore, Seattle, USA), equipped with $405 \mathrm{~nm}$ and $488 \mathrm{~nm}$ lasers for excitation, a $785 \mathrm{~nm}$ laser for a scatter signal with standard filter sets, multi magnification $(20 \times / 40 \times /$ $60 \times)$ and extended depth of field. INSPIRE software (Amnis) was used for acquisition and IDEAS software (Amnis) for analysis. The machine passed all tests and was fully calibrated prior to acquisition of samples. Before acquisition, cells were filtered through $35 \mu \mathrm{m}$ cell strainers (BD Labware). A minimum of 10,000 events per sample were acquired. Compensation matrices were generated by running single stained cells (i.e. single cell surface marker) and analysed using IDEAS software. For analysis, $\mathrm{TiO}_{2}$ positive cells were identified and quantified using a spot count analysis of dark spots appearing within the cells based on bright-field images of CD14 positive $\left(\mathrm{CD} 14^{+}\right)$cells. Briefly, cells were first plotted as area versus aspect ratio of the bright-field images and a single cell gate drawn, followed by a focused gate. $\mathrm{CD}_{14}{ }^{+}$cells were then gated based on fluorescence intensity. A custom dark spot count mask was generated to quantify $\mathrm{CD} 14^{+}$cells, with cells positive for 2 or more darks pots gated as dark spot positive.

Conventional flow cytometry analysis was performed using a CyAn ADP 9 colour analyser (Beckman Coulter, Brea, USA) equipped with $405 \mathrm{~nm}, 488 \mathrm{~nm}$ and $642 \mathrm{~nm}$ solid-state lasers and 11 detectors in standard configuration. Summit software was used for acquisition and analysis (Beckman Coulter, USA). At least 500,000 events were acquired on the flow cytometer using a lowered SSC setting on a logarithmic scale. Samples were filtered through $35 \mu \mathrm{m}$ cell strainers (BD Labware) directly prior to acquisition. For data analysis, events were first plotted as forward versus side scatter using SSC on a logarithmic scale, and a large gate was drawn excluding debris. Cells were then further gated for CD11c positivity based on fluorescence intensity for the mean fluorescence intensity (MFI) of the SSC signal of CD11c ${ }^{+}$myeloid cells.

\section{Stimulation of PBMCs with monosodium urate crystals or silica nanoparticles}

We confirmed that other exemplar inflammasomeactivating particles to which humans are exposed, namely monosodium urate (MSU) crystals and silica 
nanoparticles (SNPs) [32, 33], promote IL-1 $\beta$ processing in our short 'pulse and chase' format. Isolated PBMCs $(n=4)$ were thawed and rested overnight. Cells $\left(1.10^{6}\right.$ cells $/ \mathrm{mL}$ ) were then subjected to LPS pre-stimulation (10 ng/mL, Escherichia coli O111:B4; Sigma-Aldrich) to induce the production of pro-IL-1 $\beta$ or with TCM as a negative control. Following $3 \mathrm{~h}$, cells were washed and then challenged with $100 \mu \mathrm{g} / \mathrm{mL}$ MSU crystals (Caltag Medsystems, Buckingham, UK) or $100 \mu \mathrm{g} / \mathrm{mL}$ SNPs (InvivoGen, San Diego, USA) for a further $3 \mathrm{~h}$. Following this, cells were washed and replenished with fresh TCM for a further $21 \mathrm{~h}(3+21 \mathrm{~h})$. Supernatants were collected at the $3 \mathrm{~h}$ and $3+21 \mathrm{~h}$ time points for IL-1 $\beta$ analyses.

\section{Cytokine detection in cell supernatants}

Cell supernatants were collected at the time points indicated and stored at $-20{ }^{\circ} \mathrm{C}$ until required for cytokine analysis. IL-1 $\beta \quad\left(\mathrm{TiO}_{2}\right.$ and exemplar inflammasomeactivating particles) and TNF- $\alpha\left(\mathrm{TiO}_{2}\right.$ only) were investigated with enzyme-linked immunosorbent assay (ELISA) using DuoSet ELISA kits (R\&D Systems, Minneapolis, USA) according to the manufacturer's instructions. The cytokine concentrations were generally determined with a FlexStation 3 microplate scanner (Molecular Devices, Sunnyvale, USA) and Soft Max Pro software (Molecular Devices).

\section{Statistical analysis}

All statistical comparisons were carried out using $\mathrm{R}$ ( $\mathrm{R}$ Development Core Team, Vienna, Austria). For analysis of the flow cytometry results, the groups according to genotype (WT or $N o d 2^{\mathrm{m} / \mathrm{m}}$ BMDMs) were compared with two-way analysis of variance (ANOVA) using co-stimulation condition and $\mathrm{TiO}_{2}$ exposure as the two factors. For analysis of the cytokine secretion results without co-stimulation, the groups according to genotype (WT or $N o d 2^{\mathrm{m} / \mathrm{m}}$ BMDMs) were compared with one-way ANOVA using $\mathrm{TiO}_{2}$ exposure as the single factor. For analysis of the cytokine secretion results with co-stimulation, the groups according to co-stimulation condition (MDP or peptidoglycan) were compared with two-way ANOVA using genotype and $\mathrm{TiO}_{2}$ exposure as the two factors. In instances where two-way ANOVA results showed a significant interaction effect or the one-way ANOVA results indicated a significant difference between groups, pairwise group comparisons were performed with Tukey's post-hoc test. Figures depict group means \pm standard deviation (SD). Finally, paired $\mathrm{T}$ tests were used to compare supernatant levels of IL$1 \beta$ for cells exposed to MSU crystals or SNPs versus non-particle-exposed control cells. Group means \pm standard error of the mean (SEM) are depicted in the corresponding figure.

\section{Results}

$\mathrm{TiO}_{2}$ particle characterisation

Several images of $\mathrm{TiO}_{2}$ particles were obtained with transmission electron microscopy and a representative image is shown in Fig. 1. The diameters of individual particles were measured with image analysis software. The average primary particle size was $119 \mathrm{~nm}$ with a SD of $45 \mathrm{~nm}$, and the observed particle sizes ranged from $50 \mathrm{~nm}$ to $350 \mathrm{~nm}$ with a maximum frequency at $100 \mathrm{~nm}$ (Fig. 2a). Approximately $54 \%$ of the particles had a diameter between $125 \mathrm{~nm}$ and $200 \mathrm{~nm}$, and about 40\% had a diameter of $100 \mathrm{~nm}$ or less.

$\mathrm{TiO}_{2}$ particles were suspended in TCM for the subsequent cell culture experiments, so the particle sizes in TCM were also investigated, using nanoparticle tracking analysis. According to this method, the average particle size was $160 \mathrm{~nm}$, and the sizes ranged between $20 \mathrm{~nm}$ and $450 \mathrm{~nm}$ (Fig. 2b). Approximately $20 \%$ of the particles had a diameter of less than $100 \mathrm{~nm}$. The slight increase in particle sizes versus electron microscopy measures probably results from the differing environments as, in solution, particles have a hydration shell and are liable to adsorb TCM molecules. However, the possibility of a small degree of agglomeration in this environment cannot be precluded.

\section{Cellular effects of $\mathrm{TiO}_{2}$ particles}

As intended with our short 'pulse and chase' style assay, BMDMs of both genotypes that were not primed with LPS (i.e. sham-pulsed) did not secrete meaningful amounts of IL- $1 \beta$ when chased for $3 \mathrm{~h}$ with $\mathrm{TiO}_{2}$ from

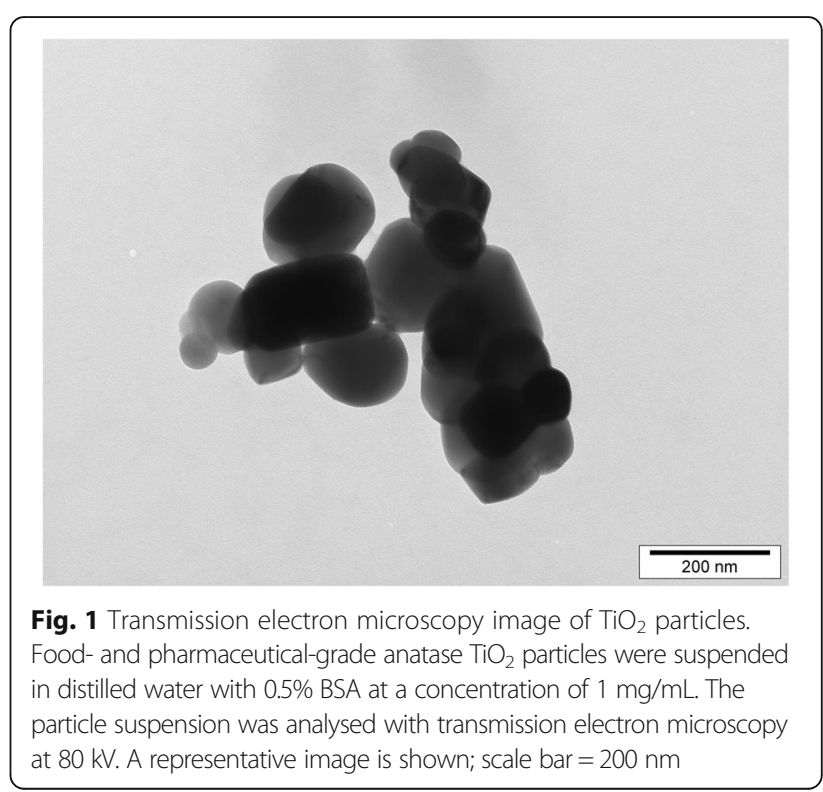




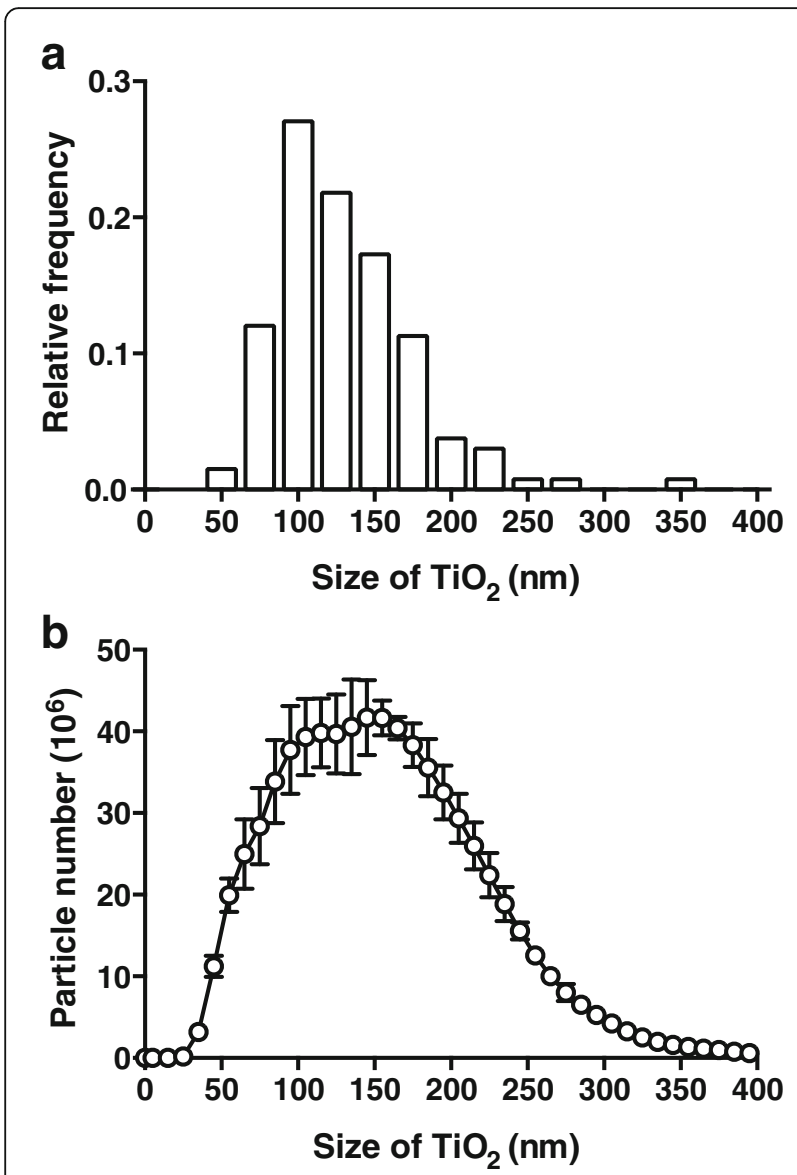

Fig. 2 Size determination of $\mathrm{TiO}_{2}$ particles. a Food- and pharmaceuticalgrade anatase $\mathrm{TiO}_{2}$ particles were suspended in distilled water with $0.5 \%$ BSA at a concentration of $1 \mathrm{mg} / \mathrm{mL}$. The particle suspension was analysed with transmission electron microscopy at $80 \mathrm{kV}$. $\mathrm{TiO}_{2}$ particle diameters were measured with image analysis software. The distribution of the particle diameters, grouped in sizes of $25 \mathrm{~nm}$, is shown as a relative frequency histogram, $n=133$. b Food- and pharmaceuticalgrade anatase $\mathrm{TiO}_{2}$ particles were suspended in RPMI 1640 medium with $10 \%$ FBS and $1 \%$ penicillin-streptomycin at a concentration of $1 \mathrm{mg} / \mathrm{mL}$. $\mathrm{TiO}_{2}$ particle sizes were determined with nanoparticle tracking analysis, and the size distribution of the particles is plotted as a line graph. Data represent mean \pm SD from three independent experiments

$0 \mu \mathrm{g} / \mathrm{mL}$ to $100 \mu \mathrm{g} / \mathrm{mL}+/-$ MDP or peptidoglycan (IL$1 \beta$ secretion always $<5 \mathrm{pg} / \mathrm{mL}$; data not shown). All subsequent data therefore refer to results with LPSprimed cells.

\section{Cell viability}

The viability of LPS-pulsed cells, from WT (Fig. 3a) and $\operatorname{Nod} 2^{\mathrm{m} / \mathrm{m}}$ mice (Fig. 3b), was significantly reduced by chasing with $\mathrm{TiO}_{2}$ particles, in a dose-responsive fashion $(p<0.001$ for trend, Fig. 3a and b). Addition of peptidoglycan or MDP during the chase phase marginally, but significantly, decreased cell viability further $(p<0.001$ for trend), although there was no interaction effect with $\mathrm{TiO}_{2}$ exposure (Fig. 3a and b).

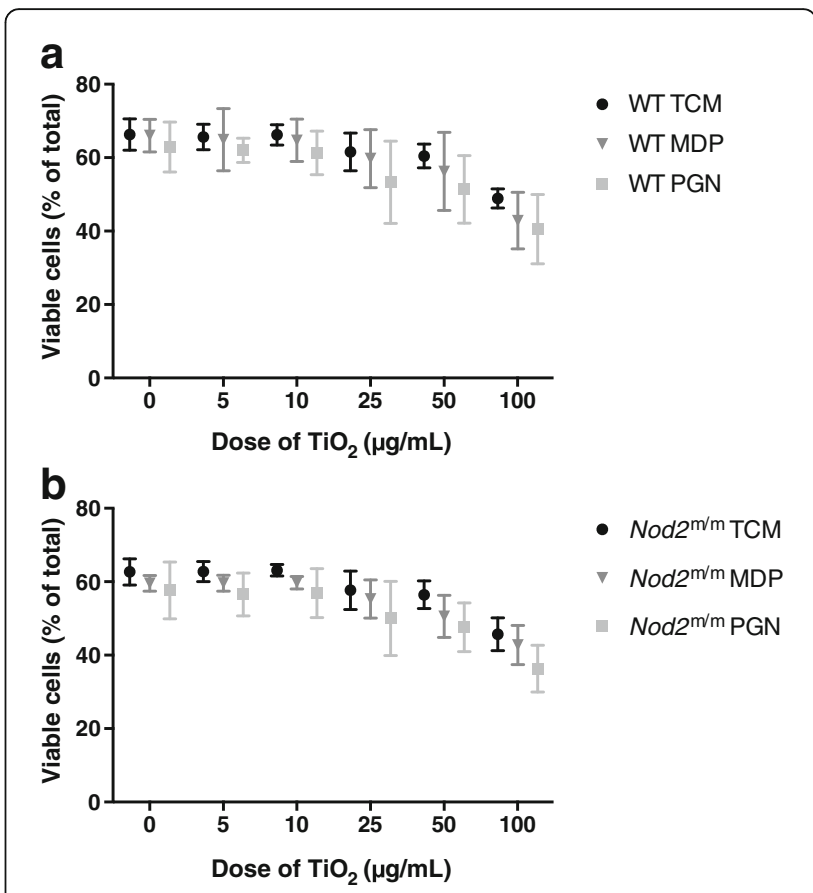

Fig. 3 Viability of LPS-primed BMDMs after chasing with $\mathrm{TiO}_{2}+/-$ peptidoglycan or MDP. BMDMs from WT (a) and Nod2 $2^{\mathrm{m} / \mathrm{m}}(\mathbf{b})$ mice were pre-stimulated for $3 \mathrm{~h}$ with LPS $(10 \mathrm{ng} / \mathrm{mL})$. Then BMDMs were incubated for $3 \mathrm{~h}$ with the indicated concentrations of $\mathrm{TiO}_{2}$ particles suspended in TCM alone (TCM), or TCM $+10 \mu \mathrm{g} / \mathrm{mL}$ MDP (MDP), or $\mathrm{TCM}+10 \mu \mathrm{g} / \mathrm{mL}$ peptidoglycan (PGN). Cells were stained with PI and F4/80 antibody for murine macrophages and analysed with flow cytometry, and viability was determined with PI exclusion. Percentages of $\mathrm{Pl}^{-}$cells in relation to the total number of detected events are shown. Data represent mean \pm SD from two independent experiments with three replicates each, $n=6$

\section{Particle uptake}

Particle uptake was assessed by flow cytometric SSC intensities for LPS-pulsed viable $\left(\mathrm{PI}^{-}\right) \mathrm{F} 4 / 80^{+} \mathrm{WT}$ (Fig. 4a) and $\operatorname{Nod} 2^{\mathrm{m} / \mathrm{m}}$ BMDMs (Fig. 4b). During the chase phase, SSC intensities of WT and Nod2 $2^{\mathrm{m} / \mathrm{m}}$ BMDMs increased with increasing $\mathrm{TiO}_{2}$ concentrations $(p<0.001$ for trend) but were unaffected by the presence of peptidoglycan or MDP (Fig. 4a and b). To confirm that such increases in SSC intensities did result from $\mathrm{TiO}_{2}$ uptake, as anticipated and as previously reported [12, 29, 30], we compared this form of analysis with imaging cytometry which allows visualisation of particle uptake [31]. Using PBMCs, and the lower end of the exposure range (where error would be greatest), increases in SSC intensity of myeloid-gated cells correlated positively and closely with observed $\mathrm{TiO}_{2}$ uptake $(r=0.84, p<0.01$; Fig. 5).

\section{IL-1 $\beta$ secretion}

In LPS-pulsed BMDMs chased with TCM alone (i.e. zero dose $\mathrm{TiO}_{2}$ in Fig. 6a), there was no secretion of mature IL-1 $\beta$, consistent with the role of LPS in stimulating pro-IL-1 $\beta$ but not triggering the inflammasome $[34,35]$. 


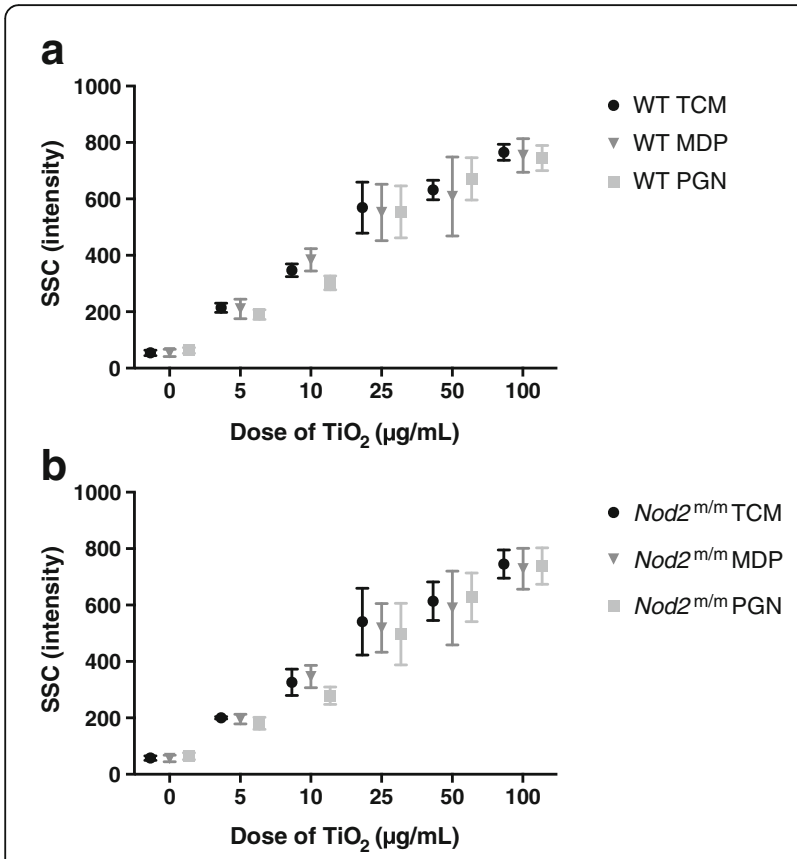

Fig. 4 Particle uptake by LPS-primed BMDMs after chasing with $\mathrm{TiO}_{2}$ $+/$ - peptidoglycan or MDP. BMDMs from WT (a) and Nod2 ${ }^{\mathrm{m} / \mathrm{m}}(\mathbf{b})$ mice were pre-stimulated for $3 \mathrm{~h}$ with LPS $(10 \mathrm{ng} / \mathrm{mL})$. Then BMDMs were incubated for $3 \mathrm{~h}$ with the indicated concentrations of $\mathrm{TiO}_{2}$ particles suspended in TCM alone (TCM), TCM + $10 \mu \mathrm{g} / \mathrm{mL}$ MDP (MDP), or TCM $+10 \mu \mathrm{g} / \mathrm{mL}$ peptidoglycan (PGN). Cells were stained with $\mathrm{Pl}$ and F4/80 antibody for murine macrophages and analysed with flow cytometry, and median SSC intensities of $\mathrm{PI}^{-} \mathrm{F} 4 / 80^{+}$cells were recorded. Data represent mean \pm SD from two independent experiments with three replicates each, $n=6$
Again as anticipated, chasing LPS-primed BMDMs with $\mathrm{TiO}_{2}$ led to mature IL- $1 \beta$ secretion in a dosedependent fashion $(p<0.001$; Fig. 6a) as these particles are a modest activator of the inflammasome $[16,28]$. Pairwise group comparison with Tukey's post-hoc test indicated significant IL-1 $\beta$ stimulation with $\mathrm{TiO}_{2}$ doses in $\mathrm{TCM}$ of $\geq 50 \mu \mathrm{g} / \mathrm{mL}$ ( $p$ between $<0.01$ and $<0.001$; Fig. 6a).

Similarly, chasing LPS-primed BMDMs with $\mathrm{TiO}_{2}+$ peptidoglycan or MDP increased IL-1 $\beta$ secretion in a dose-dependent fashion, for cells of both genotypes $(p<$ 0.001 , Fig. 6b). However, genotype significantly influenced the extent of the IL- $1 \beta$ response $(p<0.01$ for + MDP and $p<0.001$ for + peptidoglycan). Furthermore, an interaction effect between genotype and $\mathrm{TiO}_{2}$ exposure was observed for peptidoglycan $(p<0.001)$, but not for MDP. Pairwise comparisons between groups with Tukey's post-hoc test, when chasing with $\mathrm{TiO}_{2}+$ peptidoglycan, showed that the amount of IL-1 $\beta$ released by WT and $N o d 2^{\mathrm{m} / \mathrm{m}}$ BMDMs differed significantly when the cells were similarly exposed to $\geq 10 \mu \mathrm{g} / \mathrm{mL} \mathrm{TiO}_{2}$ ( $p$ between $<0.05$ and $<0.001$; Fig. $6 \mathrm{~b}$ ).

\section{TNF- $a$ secretion}

LPS priming led to marked secretion of TNF- $\alpha$ even when chased with TCM alone (Fig. 7a) because, unlike IL-1 $\beta$ [36], there is no requirement for a second signal to enable protein formation and secretion of this cytokine. Chasing LPS-primed $\mathrm{BMDMs}$ with $\mathrm{TiO}_{2}$ led to further TNF- $\alpha$ secretion in a dose-dependent fashion $(p<$ 0.001; Fig. 7a) and, again, Tukey's post-hoc test indicated significant TNF- $\alpha$ stimulation with $\mathrm{TiO}_{2}$ doses in TCM of $\geq 50 \mu \mathrm{g} / \mathrm{mL}$ ( $p$ between $<0.05$ and $<0.001$; Fig. 7a).

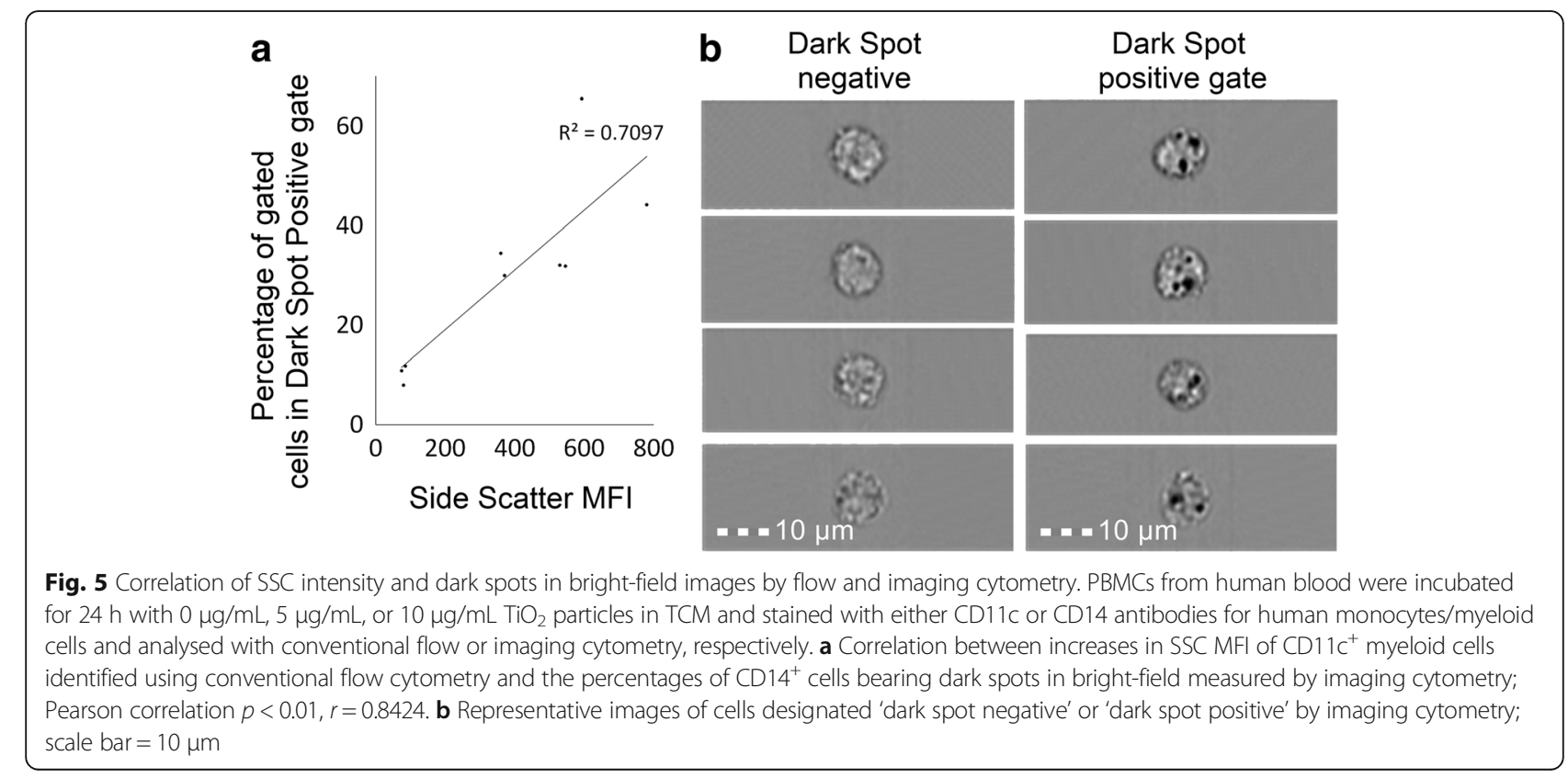




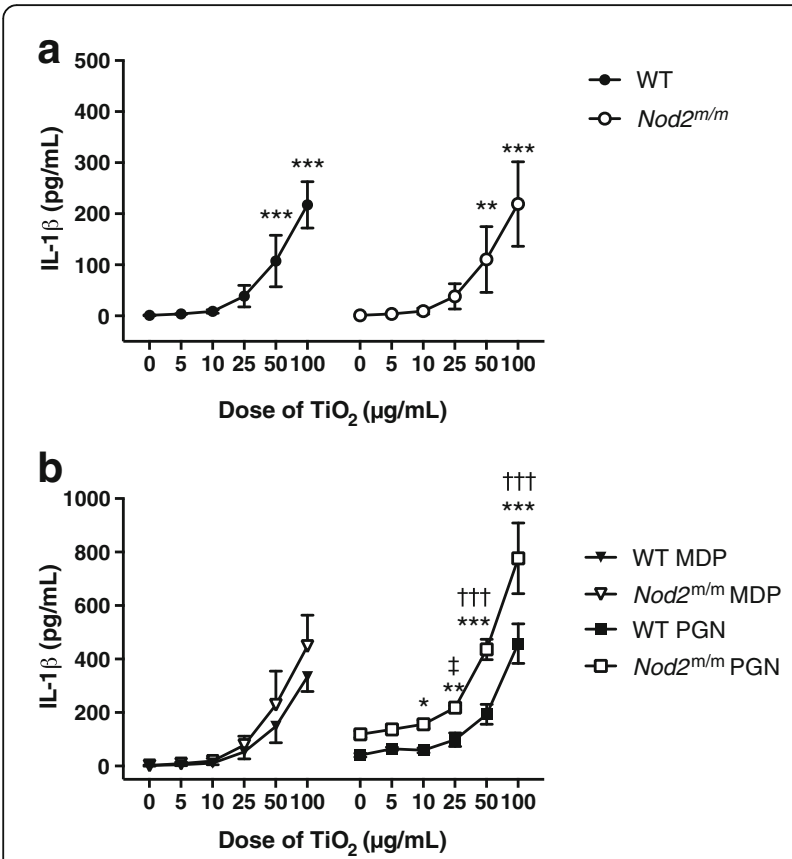

Fig. $6 \mathrm{LL}-1 \beta$ secretion by LPS-primed BMDMs after chasing with $\mathrm{TiO}_{2}$ $+/$ - peptidoglycan or MDP. BMDMs from WT and Nod $2^{\mathrm{m} / \mathrm{m}}$ mice were pre-stimulated for $3 \mathrm{~h}$ with LPS $(10 \mathrm{ng} / \mathrm{mL})$. Then BMDMs were incubated for $3 \mathrm{~h}$ with the indicated concentrations of $\mathrm{TiO}_{2}$ particles suspended in TCM alone (a) or suspended in TCM $+10 \mu \mathrm{g} / \mathrm{mL}$ MDP (MDP) or TCM $+10 \mu \mathrm{g} / \mathrm{mL}$ peptidoglycan (PGN) (b). Supernatant concentrations of IL-1 $\beta$ were analysed by ELISA. Data represent mean \pm SD from two independent experiments with three replicates each, $n=6$. a Results were analysed with one-way ANOVA and Tukey's post-hoc test; ${ }^{* *} p<0.01,{ }^{* *} p<0.001$ compared to respective WT or Nod2 $2^{\mathrm{m} / \mathrm{m}}$ cells incubated without $\mathrm{TiO}_{2}$. b Results were analysed with two-way ANOVA and Tukey's post-hoc test; ${ }^{*} p<0.05$, ${ }^{* *} p$ $<0.01,{ }^{* * *} p<0.001$ for Nod $2^{\mathrm{m} / \mathrm{m}}$ cells compared to WT cells cultured with the same $\mathrm{TiO}_{2}$ concentration, ${ }^{\mathrm{t \dagger}} p<0.001$ for WT and $\mathrm{Nod}^{\mathrm{m} / \mathrm{m}}$ cells compared to respective WT or Nod $2^{\mathrm{m} / \mathrm{m}}$ cells incubated without $\mathrm{TiO}_{2},{ }^{\ddagger} p<0.05$ for Nod $2^{\mathrm{m} / \mathrm{m}}$ cells compared to Nod $2^{\mathrm{m} / \mathrm{m}}$ cells incubated without $\mathrm{TiO}_{2}$

In contrast to IL- $1 \beta$, the secretion of TNF- $\alpha$ by LPS-primed BMDMs that were chased with MDP or peptidoglycan was not affected by additional $\mathrm{TiO}_{2}$ exposure regardless of dose (i.e. the MAMPs rather than the particles dominated the scene for TNF- $\alpha$ secretion; Fig. 7b).

Although in all cases the genotype had a significant influence $(p<0.001)$ on TNF- $\alpha$ secretion, being greater for cells from $N o d 2^{\mathrm{m} / \mathrm{m}}$ than WT mice, there was no interaction effect between genotype and $\mathrm{TiO}_{2}$ exposure (Fig. 7a and b).

\section{Specificity of $\mathrm{TiO}_{2}$ effect}

Activation of the inflammasome is by no means specific to $\mathrm{TiO}_{2}$ particles although Pele et al. have shown that correct design of in vitro experiments is critical. Notably, cell gorging of particles through extended particle
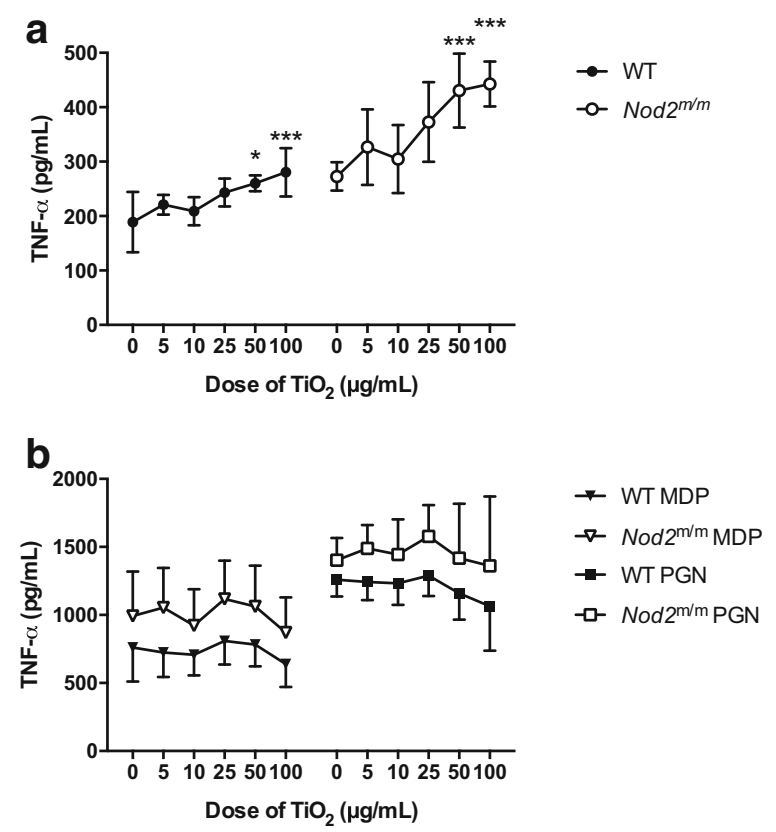

Fig. 7 TNF-a secretion by LPS-primed BMDMs after chasing with $\mathrm{TiO}_{2}+/$ - peptidoglycan or MDP. BMDMs from WT and Nod2 $2^{\mathrm{m} / \mathrm{m}}$ mice were pre-stimulated for $3 \mathrm{~h}$ with LPS (10 $\mathrm{ng} / \mathrm{mL})$. Then BMDMs were incubated for $3 \mathrm{~h}$ with the indicated concentrations of $\mathrm{TiO}_{2}$ particles suspended in TCM alone (a) or suspended in TCM + $10 \mu \mathrm{g} / \mathrm{mL}$ MDP (MDP) or $\mathrm{TCM}+10 \mu \mathrm{g} / \mathrm{mL}$ peptidoglycan (PGN) (b). Supernatant concentrations of TNF-a were analysed by ELISA. Data represent mean \pm SD from two independent experiments with three replicates each, $n=6$. a Results were analysed with one-way ANOVA and Tukey's post-hoc test; ${ }^{*} p<0.05,{ }^{* * *} p<0.001$ compared to respective WT or Nod2 ${ }^{\mathrm{m} / \mathrm{m}}$ cells incubated without $\mathrm{TiO}_{2}$

exposure (e.g. over 24 h) can lead to false positives [35]. SNPs and MSU crystals are considered exemplar particulate stimulants of the inflammasome, and we confirmed that, with similar short exposures as for our $\mathrm{TiO}_{2}$ particles $(3 \mathrm{~h})$ and LPS priming, IL-1 $\beta$ secretion was enhanced compared to non-particle-exposed cells (Fig. 8).

\section{Discussion}

\section{Relevance and context of our findings}

The distal intestinal tract is bathed in high concentrations of MAMPs such as LPS and peptidoglycan (and their fragments) due to the continuous turnover of the microbiome. Since ingested particles, such as pigmentgrade $\mathrm{TiO}_{2}$, are taken up by intestinal cells from this distal environment it is important to consider interactions of these components (i.e. MAMPs + particles) when looking at potential cellular effects. In this work we have further considered the impact of genotype, namely one that imparts greater potential for an inflammatory phenotype $\left(\operatorname{Nod} 2^{\mathrm{m} / \mathrm{m}}\right)$ than the WT version. We confirm that (a) primed cells from $\operatorname{Nod} 2^{\mathrm{m} / \mathrm{m}}$ mice secrete higher concentrations of pro-inflammatory cytokines, 


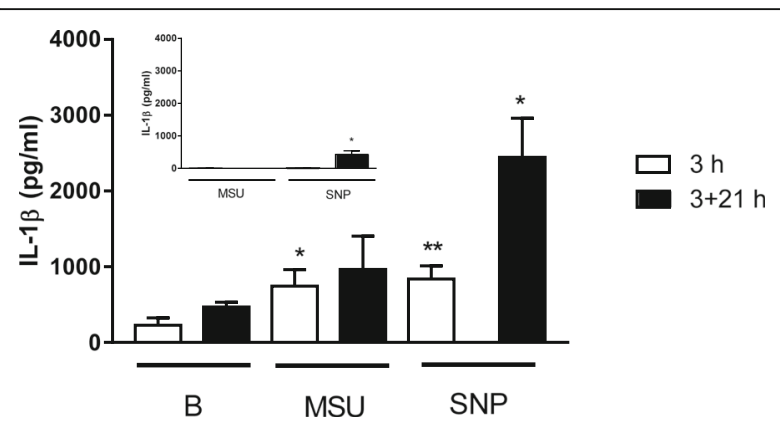

Fig. $8 \mathrm{IL}-1 \beta$ secretion by PBMCs following exposure to MSU crystals or SNPs. Secretion of IL-1 $\beta$ by PBMCs with (main figure) or without (inset) initial exposure to $10 \mathrm{ng} / \mathrm{mL}$ LPS for $3 \mathrm{~h}$ followed by exposure to MSU crystals $(100 \mu \mathrm{g} / \mathrm{mL})$ or SNPs $(100 \mu \mathrm{g} / \mathrm{mL})$ for a further $3 \mathrm{~h}$. The supernatant was either collected immediately for analysis ( 3 h; open bars) or following a further $21 \mathrm{~h}$ of cell incubation in fresh (i.e. without added particles or MAMPs) TCM (3+21 h; black bars). All data are expressed as mean \pm SEM $(n=4)$. Results were analysed by paired $T$ test in comparison to baseline (B), i.e. non-particle-exposed cells; ${ }^{*} p<0.05$ and ${ }^{* *} p<0.01$ versus respective baseline

namely IL-1 $1 \beta$ and TNF- $\alpha$, in response to MDPcontaining MAMPs than cells from WT mice [20] and (b) $\mathrm{TiO}_{2}$ particles are mediators of inflammasome activation $[12,16,28,33]$. Additionally, we show for the first time that, in primed cells exposed to peptidoglycan, the concentration of $\mathrm{TiO}_{2}$ that is required to trigger the inflammasome and induce IL- $1 \beta$ secretion is lower for cells from $\operatorname{Nod} 2^{\mathrm{m} / \mathrm{m}}$ mice than it is from WT mice. This may have important implications as discussed below.

It is established that at least some ingested $\mathrm{TiO}_{2}$ particles are taken up by intestinal cells, especially by macrophages of large lymphoid follicles of the ileum termed Peyer's patches [6-10]. Recent data suggest that cells of the large bowel can also scavenge particles of pigmentgrade $\mathrm{TiO}_{2}$ and that oral administration of this pigment can lead to pre-cancerous lesions of the colon, termed aberrant crypt foci, in about a third of WT animals but not in controls without $\mathrm{TiO}_{2}$ exposure [37]. In that work, intestinal mucosal levels of TNF- $\alpha$ and IL-1 $\beta$ were modestly increased for animals fed $\mathrm{TiO}_{2}$ versus controls [37]. Whilst our data support these findings from a cell culture perspective they also show that particle dose is critical as a determinant of the cytokine response. The precise pathway of $\mathrm{TiO}_{2}$ uptake by intestinal cells is still not understood, but it is likely that particles in the lumen have their surfaces 'decorated' by soluble molecules of the intestinal lumen so that conjugates (with MAMPs for example), rather than pristine particles, are seen by intestinal cells. Moreover, it is not clear how basal macrophages of the human Peyer's patches become loaded with particles such as $\mathrm{TiO}_{2}$ as, following $\mathrm{M}$ cell uptake, particles should be scavenged by phagocytes that are more apical than the observed basal tissue-fixed macrophages [38]. However, despite the pathway not being fully elucidated, the important point is that macrophages of the Peyer's patches do accumulate $\mathrm{TiO}_{2}$ particles in humans $[9,39]$. If, as we show here, certain genotypes require a lesser cell dose of particles to respond in a pro-inflammatory fashion compared to other genotypes then, in vivo, the initiation of a cascade of inflammation may be host-dependent as well as dosedependent.

\section{Specificity of the IL-1 $\beta$ adjuvant effect to $\mathrm{TiO}_{2}$ nanoparticles}

The 'role' of the $\mathrm{TiO}_{2}$ particles in the work presented here involves boosting the pro-inflammatory effects of MAMPs via particle-activation of the inflammasome. Many materials activate the inflammasome, including other (nano)particles, and some of these will be more potent than pigment-grade $\mathrm{TiO}_{2}$ given the modest efficacy of the latter. For example, MSU crystals and silica particles are activators of the inflammasome (as exemplified here (Fig. 8) and [28, 32, 33]) and have direct relevance in terms of human exposure. MSU crystals may precipitate ectopically and are the cause of joint inflammation in patients with gout, whilst silica exposure to the lungs is well established as an occupational hazard that leads to silicosis in miners. However, in terms of an adjuvant effect on MAMP-primed cells, $\mathrm{TiO}_{2}$ deserves particular scrutiny because (a) humans are widely exposed to it orally $[3,5]$, (b) MAMPs are ubiquitous at high concentrations in the intestinal lumen which is unlike anywhere else in the body, and (c) pigment-grade $\mathrm{TiO}_{2}$ is one of two major particle types that accumulates in intestinal (Peyer's patch) macrophages [7, 9, 39]. The second major particle type, namely aluminosilicate which is mostly in the kaolinite form [7], has not been obviously linked to inflammasome activation although this merits further careful assessment as prolonged macrophage exposure to kaolinite leads to modest IL-1 $\beta$ secretion even in the absence of MAMPS [40].

Interestingly, Winkler et al. have shown that foodgrade silica induced production of pro-IL-1 $\beta$ and secretion of mature IL-1 $\beta$ when dendritic cells were exposed to these particles [41]. In other words, silica particles have the capacity to both prime IL- $1 \beta$ formation in the precursor (pro-) form and to induce cleavage to a mature form via inflammasome activation. Although, unlike $\mathrm{TiO}_{2}$, this silica has not been demonstrated to accumulate in human intestinal immune cells [7], further studies are merited as there is significant oral exposure and perhaps intestinal cells other than those that have been so far characterised for particle accumulation in the intestine are impacted.

In summary for this section, pigment-grade $\mathrm{TiO}_{2}$ is especially relevant as a potential inflammasome adjuvant in intestinal tissue because of human exposure, 
accumulation, and activity. However, other particles, such as aluminosilicates and silica, should not be ignored as there is certainly exposure and accumulation for the former and exposure and potential for activity for the latter.

\section{$\mathrm{IL}-1 \beta$ secretion is not a simple consequence of $\mathrm{TiO}_{2}$-induced cell death}

Non-biological particles in a size range that enables phagocytosis, which includes pigment-grade $\mathrm{TiO}_{2}$, are readily engulfed by macrophages and accumulate in lysosomes [7, 9, 42]. This in turn leads to lysosomal membrane disruption which is a trigger for two concomitant events. The first is cathepsin-dependent IL- $1 \beta$ release which requires inflammasome activation, and the second is cell death which again is cathepsin-dependent but is independent of the inflammasome [42]. Hence, as expected, both events were observed in this study in a dose-dependent fashion when cells were exposed to $\mathrm{TiO}_{2}$. In vivo, cell death can lead to pro-IL-1 $\beta$ leakage into the extracellular environment and its activation through 'alternative' pathways, such as cathepsin Cneutrophil proteases. However, this does not occur in 'clean' cell culture media in vitro [42]. Moreover, a short 'pulse and chase' routine protects against such longer term complications. It is therefore anticipated that our observed IL- $1 \beta$-inducing effect of $\mathrm{TiO}_{2}$ in LPS-primed macrophages is independent of the concomitantly observed cell death. Regardless of mechanism, it does not alter the potential relevance of these findings to the in vivo situation where, as noted, pigment-grade $\mathrm{TiO}_{2}$ accumulates in selective intestinal cells of humans.

\section{In vivo relevance for health and disease}

Notwithstanding the above, and as discussed earlier, $\mathrm{TiO}_{2}$ is only a modest activator of the inflammasome, so whether realistic oral exposure to $\mathrm{TiO}_{2}$ leads to interactions with MAMPs and whether intestinal cell loading of both materials is sufficient to trigger inflammation merits closer attention in a relevant genetically susceptible model. In particular, such work should focus on (a) the Peyer's patches as sites of cellular $\mathrm{TiO}_{2}$ accumulation with the potential for early inflammatory processes [11] and (b) the colon, given the association of large bowel cancer with early inflammation and potential exacerbation of disease by $\mathrm{TiO}_{2}$ [43].

In addition, our specific interest concerns inflammatory bowel disease, especially Crohn's disease, and the potential for $\mathrm{TiO}_{2}$ as an adjuvant for pro-inflammatory responses in recipient Peyer's patch cells [7, 38, 39]. Although the murine model used here does not accurately mimic Crohn's type mutations for NOD2 because of the duplication of the 3'-end of the WT Nod2 locus [21], it does, nonetheless, have a heightened susceptibility to inflammation in response to certain MAMPs, precisely as has been proposed for Crohn's disease [44]. Further work with patient samples is therefore merited to scrutinise the potential for a $\mathrm{TiO}_{2}$ adjuvant effect on MAMPs in terms of IL- $1 \beta$ secretion.

\section{Conclusions}

In summary, in this study we have shown that dietary $\mathrm{TiO}_{2}$ particles have an impact on the production of the pro-inflammatory cytokines IL- $1 \beta$ and TNF- $\alpha$ by LPS pre-stimulated murine macrophages in vitro, and that $\mathrm{TiO}_{2}$ particles can act as IL-1 $\beta$-inducing adjuvants for bacterial MAMPs that contain MDP moieties. We also demonstrated that the impact of this adjuvant effect is genotype-dependent. Primed macrophages from $\mathrm{Nod} 2^{\mathrm{m} / \mathrm{m}}$ mice showed an elevated IL-1 $\beta$ response to incubation with $\mathrm{TiO}_{2}$ particles and peptidoglycan compared to cells from WT mice. Further work will need to consider if any human genotypes (sub-populations) are at greater inflammatory risk than the background population from $\mathrm{TiO}_{2}$ exposure.

\section{Additional files}

Additional file 1: Flow cytometry gating strategy. (DOCX $321 \mathrm{~kb}$ )

Additional file 2: F4/80 expression of LPS-primed BMDMs after chasing with $\mathrm{TiO} 2+$--peptidoglycan or MDP. (PDF $129 \mathrm{~kb}$ )

\section{Abbreviations}

ANOVA: Analysis of variance; BMDM: Bone marrow-derived macrophage; BSA: Bovine serum albumin; FBS: Foetal bovine serum; IL-1 $\beta$ : Interleukin $1 \beta$; LPS: Lipopolysaccharide; MAMP: Microbial-associated molecular pattern; MDP: Muramyl dipeptide; MFI: Mean fluorescence intensity; MSU: Monosodium urate; NLRP3: NLR family pyrin domain-containing 3; NOD2: Nucleotide-binding oligomerisation domain-containing 2; Nod $2^{\mathrm{m} / \mathrm{m}}$ : Homozygous Nod2 gene mutation (as described); PBMC: Peripheral blood mononuclear cell; PBS: Phosphate-buffered saline; PGN: Peptidoglycan; PI: Propidium iodide; pro-IL-1 $\beta$ : pro-interleukin 1 $\beta$; SD: Standard deviation; SEM: Standard error of the mean; SNP: Silica nanoparticle; SSC: Side scatter; TCM: Tissue culture medium; $\mathrm{TiO}_{2}$ : Titanium dioxide; TNF: Tumour necrosis factor; WT: Wild-type

\section{Acknowledgements}

The authors would like to thank Doug Hopcroft from the Manawatu Microscopy and Imaging Centre (Massey University, Palmerston North, New Zealand) for assistance with electron microscopy. The authors gratefully acknowledge the technical support provided by Drs Nuno Faria and Carolin Haas (Biomineral Research Group, MRC Human Nutrition Research, Cambridge, UK) for nanoparticle tracking analysis and the support for animal-related work and BMDMs preparation from Genevieve Sheriff (nee Baildon) and Ric Broadhurst (Campus Services, AgResearch, Hamilton, New Zealand), and Leigh Ryan and Dr. Wayne Young (Food Nutrition \& Health Team, Food \& Bio-based Products Group, AgResearch, Palmerston North, New Zealand). The authors are grateful for advice on statistical analysis from Dr. John Koolaard and Catherine Lloyd-West (Campus Services, AgResearch, Palmerston North, New Zealand) and comments on the manuscript from Drs Matthew Barnett and Wayne Young (Food Nutrition \& Health Team, Food \& Bio-based Products Group, AgResearch, Palmerston North, New

Zealand). The authors thank Dr. Sabine Kuhn (Institut für Klinische Chemie und Pathobiochemie, Klinikum rechts der Isar, Technische Universität München, Munich, Germany) for her kind assistance with designing the figures and three anonymous reviewers for their constructive feedback which helped to improve the manuscript. 


\section{Funding}

The research was mainly supported by the Riddet Institute through its Centre of Research Excellence funding which has been awarded to the Riddet Institute by the New Zealand government. Additional funding was provided by AgResearch, MRC Elsie Widdowson Laboratory (formerly MRC Human Nutrition Research, Grant number U105960399) and Nutrigenomics New Zealand, a collaboration between AgResearch, Plant \& Food Research, and The University of Auckland (primarily supported by funding from the Ministry for Science \& Innovation contract (11X1009). SR was supported by doctoral scholarships from Massey University and AgResearch. The funding bodies had no influence on the research or preparation of this manuscript.

\section{Availability of data and materials}

The datasets generated during and/or analysed during the current study are available from the corresponding author on reasonable request.

\section{Authors' contributions}

LCP and JJP developed the research hypothesis. LCP and SR designed the study with contributions from DEO, HS, NCR, and JJP. SR performed the experiments, analysed the results, and, together with LCP, designed the figures (except Figs. 5 and 8). REH and LCP provided the data and associated analyses for Figs. 5 and 8, respectively, and wrote the corresponding methods and results sections. All authors contributed to the interpretation of the results. SR and JJP wrote the manuscript with contributions from all authors. All authors read and approved the final manuscript.

\section{Ethics approva}

Collection of bone marrow from mice for this research was approved by the Grasslands Ethics Committee (Palmerston North, New Zealand), AgResearch Animal Ethics Committee, applications AE Tissue Collection 54 and 68 in compliance with the New Zealand Animal Welfare Act 1999.

Use of human blood for this research was approved by the ethics committee of the University of Cambridge (Cambridge, UK), Human Biology Research Ethics Committee, application HBREC.2015.10.

\section{Consent for publication}

Not applicable.

\section{Competing interests}

The authors declare that they have no competing interests.

\section{Publisher's Note}

Springer Nature remains neutral with regard to jurisdictional claims in published maps and institutional affiliations.

\section{Author details \\ ${ }^{1}$ Food Nutrition \& Health Team, Food \& Bio-based Products Group, AgResearch, Grasslands Research Centre, Tennent Drive, Private Bag 11008, Palmerston North 4442, New Zealand. ${ }^{2}$ Riddet Institute, Massey University, Private Bag 11222, Palmerston North 4442, New Zealand. ${ }^{3}$ Present address: Conreso GmbH, Neuhauser Str. 47, 80331, München, Germany. ${ }^{4}$ Biomineral Research Group, MRC Human Nutrition Research, Elsie Widdowson Laboratory, 120 Fulbourn Road, Cambridge CB1 9NL, UK. ${ }^{5}$ Present address: Center for Dairy Research, University of Wisconsin-Madison, 1605 Linden Drive, Madison, WI 53706-1565, USA. 'Department of Veterinary Medicine, Biomineral Research Group, University of Cambridge, Madingley Road, Cambridge CB3 OES, UK.}

\section{Received: 13 May 2017 Accepted: 23 November 2017}

Published online: 08 December 2017

\section{References}

1. Shi H, Magaye R, Castranova V, Zhao J. Titanium dioxide nanoparticles: a review of current toxicological data. Part Fibre Toxicol. 2013;10:15.

2. Kreyling WG, Holzwarth U, Schleh C, Kozempel J, Wenk A, Haberl N, et al. Quantitative biokinetics of titanium dioxide nanoparticles after oral application in rats: part 2. Nanotoxicology. 2017;11:443-53.

3. Lomer MCE, Hutchinson C, Volkert S, Greenfield SM, Catterall A, Thompson $\mathrm{RPH}$, et al. Dietary sources of inorganic microparticles and their intake in healthy subjects and patients with Crohn's disease. Brit J Nutr. 2004;92:947-55.
4. Powell JJ, Faria N, Thomas-McKay E, Pele LC. Origin and fate of dietary nanoparticles and microparticles in the gastrointestinal tract. J Autoimmun. 2010;34:J226-J33.

5. Rompelberg C, Heringa MB, van Donkersgoed G, Drijvers J, Roos A Westenbrink $S$, et al. Oral intake of added titanium dioxide and its nanofraction from food products, food supplements and toothpaste by the Dutch population. Nanotoxicology. 2016;10:1404-14.

6. Hummel TZ, Kindermann A, Stokkers PCF, Benninga MA, ten Kate FJW. Exogenous pigment in Peyer's patches of children suspected for inflammatory bowel disease. J Pediatr Gastr Nutr. 2014;58:477-80.

7. Powell JJ, Ainley CC, Harvey RSJ, Mason IM, Kendall MD, Sankey EA, et al. Characterisation of inorganic microparticles in pigment cells of human gut associated lymphoid tissue. Gut. 1996;38:390-5.

8. Shepherd NA, Crocker PR, Smith AP, Levison DA. Exogenous pigment in Peyer's patches. Hum Pathol. 1987;18:50-4.

9. Thoree V, Skepper J, Deere H, Pele LC, Thompson RPH, Powell JJ. Phenotype of exogenous microparticle-containing pigment cells of the human Peyer's patch in inflamed and normal ileum. Inflamm Res. 2008;57:374-8.

10. Urbanski SJ, Arsenault AL, Green FH, Haber G. Pigment resembling atmospheric dust in Peyer's patches. Mod Pathol. 1989;2:222-6.

11. Fujimura $Y$, Kamoi R, lida M. Pathogenesis of aphthoid ulcers in Crohn's disease: correlative findings by magnifying colonoscopy, electron microscopy, and immunohistochemistry. Gut. 1996;38:724-32.

12. Ashwood P, Thompson RPH, Powell JJ. Fine particles that adsorb lipopolysaccharide via bridging calcium cations may mimic bacterial pathogenicity towards cells. Exp Biol Med. 2007;232:107-17.

13. Butler M, Boyle JJ, Powell JJ, Playford RJ, Ghosh S. Dietary microparticles implicated in Crohn's disease can impair macrophage phagocytic activity and act as adjuvants in the presence of bacterial stimuli. Inflamm Res. 2007:56:353-61.

14. Evans SM, Ashwood P, Warley A, Berisha F, Thompson RPH, Powell JJ. The role of dietary microparticles and calcium in apoptosis and interleukin-1 $\beta$ release of intestinal macrophages. Gastroenterology. 2002;123:1543-53.

15. Powell JJ, Harvey RSJ, Ashwood P, Wolstencroft R, Gershwin ME, Thompson $\mathrm{RPH}$. Immune potentiation of ultrafine dietary particles in normal subjects and patients with inflammatory bowel disease. J Autoimmun. 2000;14:99-105.

16. Ruiz PA, Morón B, Becker HM, Lang S, Atrott K, Spalinger MR, et al. Titanium dioxide nanoparticles exacerbate DSS-induced colitis: role of the NLRP3 inflammasome. Gut. 2017;66:1216-24.

17. Khor B, Gardet A, Xavier RJ. Genetics and pathogenesis of inflammatory bowel disease. Nature. 2011;474:307-17.

18. Hugot JP, Chamaillard M, Zouali H, Lesage S, Cézard JP, Belaiche J, et al. Association of NOD2 leucine-rich repeat variants with susceptibility to Crohn's disease. Nature. 2001;411:599-603.

19. Ogura Y, Bonen DK, Inohara N, Nicolae DL, Chen FF, Ramos R, et al. A frameshift mutation in NOD2 associated with susceptibility to Crohn's disease. Nature. 2001;411:603-6.

20. Maeda S, Hsu LC, Liu HJ, Bankston LA, limura M, Kagnoff MF, et al. Nod2 mutation in Crohn's disease potentiates NF-KB activity and IL-1 $\beta$ processing. Science. 2005;307:734-8.

21. Maeda S. Corrections and clarifications: Nod2 mutation in Crohn's disease potentiates NF-KB activity and IL-1 $\beta$ processing [Maeda $S$ et al. (2005) Science 307(5710): 734-738]. Science. 2011;333:288.

22. Powell JJ, Thomas-McKay E, Thoree V, Robertson J, Hewitt RE, Skepper JN, et al. An endogenous nanomineral chaperones luminal antigen and peptidoglycan to intestinal immune cells. Nat Nanotechnol. 2015;10:361-9.

23. Klasen IS, Melief MJ, van Halteren AG, Schouten WR, van Blankenstein M, Hoke $\mathrm{G}$, et al. The presence of peptidoglycan-polysaccharide complexes in the bowel wall and the cellular responses to these complexes in Crohn's disease. Clin Immunol Immunopathol. 1994;71:303-8.

24. Filipe $V$, Hawe A, Jiskoot W. Critical evaluation of nanoparticle tracking analysis (NTA) by NanoSight for the measurement of nanoparticles and protein aggregates. Pharm Res. 2010;27:796-810.

25. Roy N, Barnett M, Knoch B, Dommels Y, McNabb W. Nutrigenomics applied to an animal model of inflammatory bowel diseases: transcriptomic analysis of the effects of eicosapentaenoic acid- and arachidonic acid-enriched diets. Mutat Res. 2007;622:103-16.

26. Morishige T, Yoshioka Y, Tanabe A, Yao X, Tsunoda S, Tsutsumi Y, et al. Titanium dioxide induces different levels of IL-1 $\beta$ production dependent on its particle characteristics through caspase-1 activation mediated by reactive oxygen species and cathepsin B. Biochem Biophys Res Commun. 2010;392:160-5. 
27. Palomäki J, Karisola P, Pylkkänen L, Savolainen K, Alenius H. Engineered nanomaterials cause cytotoxicity and activation on mouse antigen presenting cells. Toxicology. 2010;267:125-31.

28. Winter M, Beer HD, Hornung V, Kärmer U, Schins RPF, Förster I. Activation of the inflammasome by amorphous silica and $\mathrm{TiO}_{2}$ nanoparticles in murine dendritic cells. Nanotoxicology. 2011;5:326-40.

29. Suzuki H, Toyooka T, Ibuki Y. Simple and easy method to evaluate uptake potential of nanoparticles in mammalian cells using a flow cytometric light scatter analysis. Environ Sci Technol. 2007:41:3018-24.

30. Zucker RM, Massaro EJ, Sanders KM, Degn LL, Boyes WK. Detection of $\mathrm{TiO}_{2}$ nanoparticles in cells by flow cytometry. Cytometry A. 2010;77:677-85.

31. Hewitt RE, Vis B, Pele LC, Faria N, Powell JJ. Imaging flow cytometry assays for quantifying pigment grade titanium dioxide particle internalization and interactions with immune cells in whole blood. Cytometry A. 2017;91A:1009-20.

32. Martinon F, Pétrilli V, Mayor A, Tardivel A, Tschopp J. Gout-associated uric acid crystals activate the NALP3 inflammasome. Nature. 2006;440:237-41.

33. Yazdi AS, Guarda G, Riteau N, Drexler SK, Tardivel A, Couillin I, et al. Nanoparticles activate the NLR pyrin domain containing 3 (NIrp3) inflammasome and cause pulmonary inflammation through release of IL-1a and IL-1ß. Proc Natl Acad Sci U S A. 2010;107:19449-54.

34. Latz E, Xiao TS, Stutz A. Activation and regulation of the inflammasomes. Nat Rev Immunol. 2013;13:397-411.

35. Pele L, Haas CT, Hewitt R, Faria N, Brown A, Powell J. Artefactual nanoparticle activation of the inflammasome platform: in vitro evidence with a nanoformed calcium phosphate. Nanomedicine (Lond). 2015;10:1379-90.

36. Dinarello CA. Immunological and inflammatory functions of the interleukin1 family. Annu Rev Immunol. 2009;27:519-50.

37. Urrutia-Ortega IM, Garduno-Balderas LG, Delgado-Buenrostro NL, FreyreFonseca V, Flores-Flores JO, Gonzalez-Robles A, et al. Food-grade titanium dioxide exposure exacerbates tumor formation in colitis associated cancer model. Food Chem Toxicol. 2016;93:20-31.

38. Powell JJ, Thoree V, Pele LC. Dietary microparticles and their impact on tolerance and immune responsiveness of the gastrointestinal tract. $\mathrm{Br} J$ Nutr. 2007;98(Suppl 1):S59-63.

39. Lomer MCE, Thompson RPH, Powell JJ. Fine and ultrafine particles of the diet: influence on the mucosal immune response and association with Crohn's disease. Proc Nutr Soc. 2002:61:123-30.

40. Kato T, Toyooka T, Ibuki Y, Masuda S, Watanabe M, Totsuka Y. Effect of physicochemical character differences on the genotoxic potency of kaolin. Genes Environ. 2017;39:12.

41. Winkler HC, Kornprobst J, Wick P, von Moos LM, Trantakis I, Schraner EM, et al. MyD88-dependent pro-interleukin-1 $\beta$ induction in dendritic cells exposed to food-grade synthetic amorphous silica. Part Fibre Toxicol. 2017;14:21.

42. Orlowski GM, Sharma S, Colbert JD, Bogyo M, Robertson SA, Kataoka H, et al. Frontline science: multiple cathepsins promote inflammasomeindependent, particle-induced cell death during NLRP3-dependent IL-1ß activation. J Leukoc Biol. 2017;102:7-17.

43. Bettini S, Boutet-Robinet E, Cartier C, Comera C, Gaultier E, Dupuy J, et al. Food-grade $\mathrm{TiO}_{2}$ impairs intestinal and systemic immune homeostasis, initiates preneoplastic lesions and promotes aberrant crypt development in the rat colon. Sci Rep. 2017;7:40373.

44. de Souza HSP, Fiocchi C, lliopoulos D. The IBD interactome: an integrated view of aetiology, pathogenesis and therapy. Nat Rev Gastroenterol Hepatol. 2017; doi:10.1038/nrgastro.2017.110

\section{Submit your next manuscript to BioMed Central and we will help you at every step:}

- We accept pre-submission inquiries

- Our selector tool helps you to find the most relevant journal

- We provide round the clock customer support

- Convenient online submission

- Thorough peer review

- Inclusion in PubMed and all major indexing services

- Maximum visibility for your research

Submit your manuscript at www.biomedcentral.com/submit

CBiomed Central 